\title{
Chemical Quality and Sediment Content of Runoff Water from Southeastern Montana Rangeland
}

EARL L. NEFF

\section{Abstract}

Chemical quality of surface runoff water from rangeland sites with fine-textured soils in southeastern Montana was good to excellent with average total dissolved solids $<300 \mathrm{mg} /$ liter. This quality is better than that of most municipal water supplies in the same geographic area. Erosion from these sites was also low, averaging $<1,500 \mathrm{~kg} / \mathrm{ha}$ per year.

Surface runoff stored in small ponds is the main water supply for range livestock in the northern Great Plains because most streams are ephemeral and suitablc ground water is too deep for economical well drilling. Most previous investigations have studied quantity rather than quality of stock water supplies, but Soiseth (1975) reported that runoff and reservoir water quality in southeastern Montana was good to fair, and that the chemical quality of water stored in ponds could deteriorate to poor during the grazing season as water levels decrease by evaporation.

Author is research hydraulic engineer, U.S. Dep. Agr., Agr. Res. Serv., P.O. Box 1109 Sidney, Montana.

This report is a contribution from the Western Region, U.S. Dep. Agr., Agr. Res., Serv., in cooperation with the Bureau of Land Management, U.S. Dep. Interior, and the Montana Agr. Exp. Sta., Journal Series No. 1092.
The objective of the study reported here was to assess the chemical quality and sediment content of runoff water from finetextured rangeland soil in southeastern Montana.

\section{Site Description and Methods}

This study was conducted about $29 \mathrm{~km}$ south of Ekalaka in southeastern Montana. The climate is arid to semiarid continental, with cold, dry winters and warm summers. Average annual precipitation is about $300 \mathrm{~mm}$.

Runoff samples were collected from 10, 0.8-ha watershedseight on claypan range site where the average slope is 1 to $5 \%$ and two on a saline-upland range site where the average slope is $3 \%$. Soils of the claypan range site are in the Bickerdyke and Bascovy series, which are members of the very fine and fine, respectively, montmorillonitic, Borollic Vertic Camborthids. The soils of the saline-upland range site are in the Dilts series, a member of the family of clayey, montmorillonitic, acid, frigid, shallow Ustic Torriorthents. Vegetation on the claypan site included thickspike wheatgrass (Agropyron dasystachyum), western wheatgrass (A. smithii), Sandberg bluegrass (Poa secunda), junegrass (Koeleria cristata), big sagebrush (Artemisia tridentata), and pricklypear cactus (Opuntia polycantha). Blue grama (Bouteloua gracilis), buffalograss (Buchloe dactyloides), and clubmoss (Selaginella densa) dominated small residual pedestals of coarse-textured material. On the saline-upland range site, alkali sacaton (Sporobo- 


\begin{tabular}{|c|c|c|c|c|c|c|c|c|c|c|c|c|}
\hline & \multicolumn{6}{|c|}{ Saline-upland range site } & \multicolumn{6}{|c|}{ Claypan range site } \\
\hline & \multicolumn{3}{|c|}{ Unfurrowed } & \multicolumn{3}{|c|}{ Furrowed } & \multicolumn{3}{|c|}{ Unfurrowed } & \multicolumn{3}{|c|}{ Furrowed } \\
\hline & Max. & Min. & Avg. & Max. & Min. & Avg. & Max. & Min. & Avg. & Max. & Min. & Avg. \\
\hline Elec. conductivity, mmhos $/ \mathrm{cm}$ & 0.58 & 0.10 & 0.23 & 0.83 & 0.30 & 0.42 & 0.35 & 0 & 0.06 & 0.13 & 0 & 0.06 \\
\hline Manganese, mg/liter & 0.07 & 0 & 0.02 & 0.02 & 0 & 0.01 & 0.07 & 0 & 0.01 & $\mathbf{N R}^{2}$ & NR & NR \\
\hline Iron, mg/liter & 17.30 & 0 & 3.00 & 0.05 & 0 & 0.02 & 9.16 & 0.39 & 1.80 & NR & NR & NR \\
\hline Calcium, mg/liter & 0.59 & 0.01 & 0.22 & $* 1$ & * & 1.52 & 0.15 & 0 & 0.04 & 0.10 & 0.05 & 0.08 \\
\hline Magnesium, mg/liter & 0.47 & 0.01 & 0.11 & $*$ & $*$ & 0.49 & 0.04 & 0 & 0.01 & 0.03 & 0.02 & 0.03 \\
\hline Sodium, mg/liter & 7.50 & 1.10 & 3.30 & $*$ & * & 13.40 & 1.52 & 0.45 & 0.88 & 1.76 & 0.78 & 1.30 \\
\hline Total dissolved solids, mg/liter & 390 & 0 & 100 & 600 & 160 & 250 & 200 & 0 & 10 & 20 & 0 & 7 \\
\hline Sediment, $\mathrm{mg} /$ liter & 3615 & 315 & 1650 & 3835 & 710 & 1670 & 1085 & 95 & 390 & 660 & 215 & 370 \\
\hline
\end{tabular}

'Results from one sample.

${ }^{2} \mathrm{NR}=$ No record.

lus airoides), Nuttall alkaligrass (Puccinellia airoides), and Nuttall saltbush (Atriplex nuttallii) were the dominant plants. Half of the watersheds at each site were contour furrowed with a RM-25 (Vallentine 1971) contour furrower. Runoff samples were collected by automatic pumping-type samplers that drew samples at 10 minute intervals during each runoff event. These samples were analyzed by routine laboratory procedures to determine electrical conductivity, major cations, and sediment content. Total dissolved solids were computed from the equation:

$$
\text { TDS }=0.819(E C)-86.9
$$

where:

$$
\begin{aligned}
\mathrm{TDS}= & \text { total dissolved solids in } \mathrm{mg} / \text { liter, and } \\
\mathrm{EC}= & \text { electrical conductivity in micromhos } / \mathrm{cm} \\
& \text { at } 25^{\circ} \mathrm{C} .
\end{aligned}
$$

Equation [1] has a correlation coefficient equal to 0.99 and was developed (Soiseth 1975) from water samples collected during a study in the same general geographic area in 1971-1973.

Samples were collected from all of the unfurrowed watersheds, but only two of the furrowed watersheds produced runoff, because rainfall during this period of record did not exceed the furrow water storage capacity on the other three furrowed watersheds during any single storm.

\section{Results and Discussion}

I collected more than 300 water samples during runoff events in 1977 and 1978. About 1/3 of these were randomly selected for initial laboratory analysis to determine whether the amount and range of chemicals were great enough to justify analyzing all samples. Results from 97 samples are summarized in Table 1. Since each of the subsamples was well within acceptable quality standards and since the ranges of values in the subsamples were relatively narrow, I decided that it was unnecessary to analyze the remaining 200 samples to assess the runoff water quality.

Runoff events from the contour furrowed watersheds were few, so the results shown for these watersheds represent fewer samples than do the results for the unfurrowed watersheds. In addition to the tests shown in Table $1, I$ also tested a few samples for nitrate nitrogen and phosphate phosphorus. The maximum amount of nitrogen measured in any sample was $0.06 \mathrm{mg} /$ liter, and the nitrogen content of most samples was only a trace. The phosphorus content was less than $0.2 \mathrm{mg} /$ liter.

Because no single ion tested or measured was present in harmful amounts, the best way to describe the quality of this water is by total dissolved solids (TDS). Soiseth (1975) presented a table that defined livestock water quality as "good" if the TDS value is between 0 and 1,000 mg/liter while others (Stephenson 1973; Wetchert and Freeman 1970) listed $5,000 \mathrm{mg} /$ liter dissolved solids as the upper limit for consumption by livestock. Of the samples reported here, even those with the highest concentrations $(600$ $\mathrm{mg} /$ liter) are well below this upper limit. In fact, these samples are of better quality than many of the domestic and municipal water supplies in eastern Montana. For example, the TDS in the municipal water supply in Sidney, Montana, is $1,000 \mathrm{mg} /$ liter; in Baker, Montana, it is $1,200 \mathrm{mg} /$ liter; and in Ekalaka it is $600 \mathrm{mg} /$ liter.

There is some indication that the salt content of runoff water increases with increasing contributing area. The TDS of samples collected in June 1977 from the 0.8-ha experimental watersheds averaged about $150 \mathrm{mg} /$ liter; a sample from Buffalo Creek, with a drainage a rea of about 4,000 ha, taken in May 1977, had about 600 $\mathrm{mg} /$ liter; and a sample from Box Elder Creek, with a drainage area of about 260,000 ha, also taken in May 1977, had about 850 $\mathrm{mg} /$ liter. The samples from the larger drainage areas were taken during a time of relatively high discharge and the concentrations probably increased during the season as the flow subsided.

Contour furrowing did not affect the sediment concentrations of samples from either the saline-upland or the claypan range site. On the saline-upland site, sediment concentrations averaged about $1,700 \mathrm{mg} /$ liter from both the furrowed and the unfurrowed areas. On the claypan site, they averaged about $400 \mathrm{mg} /$ liter. These concentrations represent sediment yields of about $170 \mathrm{~kg} /$ ha per $\mathrm{cm}$ of runoff from saline-upland range site and about $40 \mathrm{~kg} / \mathrm{ha}$ per $\mathrm{cm}$ of runoff from the claypan range site. Converting these concentrations to annual yield values results in the estimates that the long-term average annual sediment yield from the saline-upland range site will not exceed $1,400 \mathrm{~kg} / \mathrm{ha}$ per year from the native range uplands and $650 \mathrm{~kg} /$ ha per year from the contour-furrowed areas. Comparable values for the claypan range sites are 225 and $120 \mathrm{~kg} /$ ha per year. These values compare favorably with the rangeland soil loss tolerance of $4,500 \mathrm{~kg} /$ ha per year established by the U.S. Department of Agriculture (U.S. Dep. Agr., Resources Conservation Act Coordinating Committee 1980; Wight and Siddoway 1980).

Because these values are so low, other erosion characteristics are of little more than academic interest, since it is questionable how applicable these results are to other areas with higher erosion rates. However, there are two observations that I should note.

1. Sediment concentration appears to be much lower during periods of snowmelt than during periods of rainfall runoff. This is only an indication because in most cases the sediment samplers were not operating during snowmelt periods because of the possibility of equipment damage from freezing. However, runoff samples were taken during two snowmelt events. The first of these was in May 1972, when a late-season snowstorm occurred after the samplers were placed in operation for the summer. The second event occurred in September 1973, when an early-season snowstorm occurred before the samplers were shut down for the winter. Only a trace of sediment was in the samples collected during the first snowmelt event; all the sediment was held in suspension, and no particles were visible to the naked eye. Sediment concentration in samples from the second snowmelt event averaged $400 \mathrm{mg} /$ liter from the saline-upland range site and $70 \mathrm{mg} /$ liter from the claypan range sites.

2. On both the claypan and the saline-upland range sites the sediment concentrations during midsummer thunderstorm events 
tended to be highest at the beginning of the runoff event and to decline rapidly to a relatively constant concentration for the remainder of the event. In contrast, concentrations were lower and fairly uniform throughout both early- and late-season runoff events. This difference is probably related to the higher rainfall intensities and shorter durations associated with thunderstorm events.

\section{Conclusion}

Two conclusions may be reached from this study:

1. The chemical quality of surface runoff water from salineupland and claypan range sites in southeastern Montana is good to excellent. It is, in fact, better than the quality of many municipal water supplies in the same area.

2. Erosion rates from these upland watersheds are well below acceptable limits and do not significantly contribute to downstream sediment loads. Downstream sediment yield apparently results from bank and channel erosion that occurs after surface runoff becomes concentrated and channelized in rates and amounts with sufficient erosive power for particle detachment and transport.

\section{Literature Cited}

Soiseth, R.J. 1975. Runoff and reservoir quality for livestock use in southeastern Montana. J. Range Manage. 28:344-348.

Stephenson, Gordon R. 1973. Stock-water development from 2 shallow aquifer systems on south west Idaho rangeland. p. 156-168. In: Proceedings of the Water-Animal Relations Symposium, Twin Falls, Idaho, June 26-28, 1973, H.F. Mayland, General Editor. Univ. of Idaho, Soc. Range Manage., West. Sec. Amer. Soc. of Animal Sci.

U.S. Department of Agriculture, Resources Conservation Act Coordinating Committee. 1980. Soil and Water Resources Conservation Act: Program report and environmental impact statement 1980, Review Draft.

Vallentine, J.F. 1971. Special range treatments. p. 301-314. In: Range Development and Improvements. Brigham Young Univ. Press, Provo, Utah.

Wetchert, W.T., and Barry Freeman. 1970. "Horizontal" wells. Paper No. 70-721, Amer. Soc. Agr. Engin., presented at Winter Meeting, Dec. 8-11.

Wight, J. Ross, and F. Siddoway. 1980. Determinants of soil loss tolerance: Rangelands. Amer. Soc. Agron. Special Pub. (In press). 